\title{
ONKO FENOMENOLOGIALLA YHä ASIAA?
}

Die erscheinende Welt, Festschrift für Klaus Held, Herausgegeben von Heinrich Hüni und Peter Trawny, Duncker \& Humblot, Berlin 2002.

"Asioihin itseensä!" oli se iskulause, jonka ympärille satakunta vuotta sitten syntyi fenomenologinen liike, filosofinen suuntaus, jossa vastustettiin kirjojen kirjoittamista kirjoista, käsitteiden rakentamista toistensa varaan ja teoretisointia teorian vuoksi. Tämä ajatus keskittymisestä asiaan itseensä ei ollut uusi vaan periytyi antiikista asti. Platonin Seitsemännen kirjeen jälkeen teemaan onkin historiassamme palattu aina uudestaan. Paluu on ollut tarpeen, sillä asioihin paluulla on taipumus vesittyä ja taipua kohden käsitteiden pyörittelyä. Fenomenologinen liike ei tässä muodosta historiallista poikkeusta.

Ajan myötä fenomenologisen liikkeen alkuperäinen henki selvittää asioita itseään on kääntynyt kohti arkkifenomenologien tekstien, käsitteiden ja jopa teorioiden esittelyä, selittelyä sekä järjestelyä. Teksteistä on etsitty kaivattua argumentaatiota, vaikka alkuperäinen fenomenologia pyrkikin selvittämään pikemminkin niitä lähtökohtia, joista argumentaatio alkaa. Husserlja Heidegger-tutkimuksella on varmasti välillinen arvonsa jopa asioiden itsensä kannalta, mutta samalla on suuri vaara haihduttaa fenomenologisen liikkeen alkuperäinen henki. Nykyisessä yliopistomaailman ilmapiirissä julkaisutehokas käsitteiden ja teorioiden vertailu on paremmin kotonaan kuin vaivalloinen, hidas ja riskialtis asiaan itseensä paneutuminen. Fenomenologia onkin pitkälti korvautunut fenomenologisten tekstien argumentaation selvityksellä.

Osa akateemisesta yhteisöstä on kuitenkin pyrkinyt pitämään kiinni fenomenologian alkuperäisestä pyrkimyksestä. Saksan fenomenologisen seuran vuosikirjasta (Phänomenologische Forschungen, Felix Meiner Verlag) löytyy aina muutama artikkeli, joissa asia on etusijalla ja sitaatit vain tukevat sitä. Husserl-tutkimuksen vahvin ammattitaito on perinteisesti löytynyt Leuvainin ja Kölnin Husserl-arkistojen tiimoilta. Tämän kirjoittajalle on jäänyt myös vaikutelma, että akateeminen ammattitaito tälle tasolle vietynä saattaa jo kääntyä jopa asioita kohden. Fenomenologia on noilla seuduilla vaikuttanut elinvoimaiselta, vaikka sisältö silloin tällöin hukkuukin Husserl-sitaatteihin. Kun asian ottaa puheeksi, tulee usein esiin nimi Klaus Held.

Klaus Held on Ludwig Landgreben, Husserlin assistentin oppilas. Hän oli Bergische Universität Wuppertalin ensimmäinen filosofian oppituolin haltija (vuodesta 1974) ja toimi pitkään Saksan fenomenologisen seuran (Deutsche Gesellschaft für phänomenologische Forschung) puheenjohtajana (1987-94). Heldin dissertaatio vuodelta 1966 käsittelee Husserlin maineikkaita julkaisemattomia käsikirjoituksia elävästä nykyisyydestä (Lebendige Gegenwart, tulossa myös englanniksi). Vaikka Heldin habilitaatio tarkastelee antiikin filosofian lähtökohtia, kiinnostus Husserliin ja fenomenologiaan pysyi yhä hänen keskeisenä kiinnostuksen kohteenaan. Myöhemmässä tuotannossa painopiste ulottuu myös politiikan ajatteluun ja kulttuurien välisiin suhteisiin. Heldin tuotanto ei ole poik- keuksellisen laaja, mutta vaikutus fenomenologiseen ilmapiiriin näyttää välittyneen muutoinkin kuin kirjoitusten kautta. Tätä käsitystä tukee myös hänen 65-vuotispäivänsä kunniaksi julkaistu juhlakirja Die erscheinende Welt. Liki 800-sivuinen kirja sisältää 42 artikkelia, ja kirjoittajia löytyy Heldin myöhäisteemoja vastaten ympäri maapalloa.

Teos alkaa Berhard Waldenfelsin hienolla artikkelilla muistamisesta ja unohtamisesta ("Leibhaftiges Vergessen und Erinnern"). Waldenfelshan johti yhdessä Heldin kanssa Wuppertalin ja Bochumin yliopistojen maineikasta jatko-opintoseminaaria Phänomenologie und Hermeneutik 1990-luvulla. Artikkeli pitääkin esillä muistamisen ja unohtamisen kokemuksia ja tuo niiden aspekteja esiin nojautuen oivalluksiin koko filosofian historian laajuudelta. Teoksesta löytyy muitakin asialähtöisiä tutkimuksia: Felix O'Murchadhan artikkeli "Ruin als Werk" katselee Irlannin raunioita ja miettii, kuinka menneisyys niissä on nykyistä. Pahan tekemisen kohdalla vaatimus omasta kokemuksesta on jo hieman liikaa, mutta Georg Siegmannin artikkeli "Selbstverwirklichung als Lebenslüge" tavoittaa kuitenkin asiallisen lähtökohdan Augustinuksen Tunnustusten päärynävarkaus-kertomuksessa, ensimmäisestä pahaa koskevasta filosofisesta selvityksestä. Myös vaikkapa Motoaki Nakadan "Phänomenologie der Fremderfahrung der Anderen" havainnollistaa aihettaan hyvin. Intersubjektiivisuutta ei lähdetä tarkastelemaan käsitteistä vaan esillä pidetään kokemuksia: luokkahuoneen ja kuorolaulun tapahtumia. Antonio 
F. Aguirren artikkeli "Das intentionale Geflecht des Bewusstseinslebens" paneutuu fenomenologiseen ydinteemaan siitä, etten näe väriaistimuksia tai kuule ääniaistimuksia vaan näen värillisiä esineitä ja kuulen vaikkapa laulua. Eikö ääni pimeässä metsässä aina ole vaikkapa pienen eläimen liikahdus tai tuulen heilauttama oksa eikä puhdas ääni, jolle alkaisimme sitten keksiä tulkintaa tai syytä?

Teemojen suhteen juhlakirja poikkeaa fenomenologian valtavirrasta selkeimmin Maan käsittelyssä. John Sallisin ("Die elementare Erde"), Raphael Célisin ("Die Phänomenologie und das Reisen im Weltraum") sekä Dean Komelin ("Die Erde als phänomenologische Thema”) artikkelit käsittelevät teemaa eksplisiittisesti, ja muissakin artikkeleissa Maa tulee esiin usein. Useinhan Maan teema on tyydytty jättämään luonnontieteiden kokeellisten teorioiden armoille. Kirjan selvityksissä Maasta ei tosin sinällään ole juurikaan mitään uutta tai yllättävää: kun kulttuurimme tapaan mallintaa Maa esineeksi muiden joukossa - vaikka sitä ei sellaisena koskaan koeta - otetaan etäisyyttä, tulee tilaa nähdä Maa siten kuin se meille todella ilmenee.

Kirjan tekstilähtöisempäänkin materiaaliin sisältyy muutama erinomainen artikkeli. Jean-François Courtinen "Vom Logos zur Sprache" jäsentää hienosti Heideggerin näkemystä logoksesta. Franco Volpin "Das problem der Aisthesis bei Aristotle" rakentuu pitkälti Wolfgang Welschin Aisthesisteokselle, mutta antaa Welschin näkemykselle lisää painoa. Perinteinen logos-keskeinen luenta Aristoteleesta saa rinnalleen näkemyksen, jossa Aristoteleen ajattelun perusakseli sijoittuu aistimellisuuteen (aisthesis). Aistimellisuuden Aristoteles taas saattoi hyvinkin ajatella laajemmin ja perusteellisemmin kuin kukaan hänen jälkeensä. Myös Hans Reiner Seppin ("Zeit und Sorge, Eine Anmerkung zu Heideggers kritik an Husserl") ja László Tengelyin ("Erfahrung und Ausdruck bei Kant") artikkelit ovat vakuuttavaa työtä, ja Jairo Escobar Moncadan "Sprache und Sein in Platons Sophistes" on kiitettävän selkeä esitys.

Juhlakirjaa lukiessa huomio kiinnittyy myös japanilaisten tutkijoiden vahvoihin jäsennyksiin. Näissä asia nähdään toisesta näkökulmasta kuin mihin Euroopassa on totuttu. Kun näkemykset ovat selvästikin huolella pohdittuja syntyy tästä raikas tuulahdus vanhoihin asetelmiin. Kiyoshi Sakai ("Die Fensterlosigkeit der Monade, Ein Aspekt der Frage nach dem Anderen") asettaa itselleen kohtuuttoman oloisen tehtävän pyrkiessään ketjuttamaan Russellin, Husserlin, Heideggerin, Finkin/Rombachin, Nishidan ja Beckettin tulkinnat Leibnizin monadeista. Sakai kuitenkin selviää tehtävästä kuivin jaloin ja esittää samalla kiinnostavia löytöjä japanilaisesta Beckett-tutkimuksesta. Shinji Hamauzu ("Zur Phänomenologie des Unsichtbaren bei Husserl und Heidegger") taas onnistuu osoittamaan varsin vakuuttavasti, että Heideggerin olisi metodinsa kannalta ollut parempi jatkaa Husserlin työn seuraamista myös 1920-luvulla. Toru Tani ("Zeichen, Gegenwart und Ich") taas saa Derridan vaikuttamaan huolimattomalta lukijalta käydessään uudelleen läpi hänen luentaansa Husserlista.

Juuri Japanissa fenomenologialla onkin pitkä perinne: japanilaisia tutkijoita vieraili usein Husserlin seminaarissa jo 1920-luvulla. Juhlakirjasta käy myös ilmi, että joukossa oli myös kiinalainen tutkija, mutta hänen henkilöllisyyttään ei vielä ole saatu selville. Laajemmin Husserlia onkin Kiinassa tunnettu vasta 1970luvun lopulta lähtien. Toisaalta Husserliin on tuskin missään tutustuttu tässä mittakaavassa: Fenomenologian idean käännöstä (1986) on jo myyty yli 130000 kappaletta (Liangkang Ni, "Husserl-Rezeption in China").

Kokoelmaan sisältyy tietenkin muutama heikkokin artikkeli. Kokonaisuutena kirja on kuitenkin sekä kiinnostava että vakuuttava osoitus siitä, että fenomenologialla on yhä asiaa, vaikka juuri tuossa asiallisuudessaan teos ei kaikkia toiveita täytäkään. Nykyäänhän fenomenologia on useimmiten muodostunut logofaniaksi, jossa ei pyritäkään saamaan ilmiötä (fainomenon) yhteiseen puheeseen (logos) vaan päinvastoin selvittämään sanomaamme ilmiöin. Käytännössä tutkija ottaa Husserlin käsitteen, vaikkapa noeman, ja koettaa löytää sille vastinetta ilmiöistä. Kielifilosofian paine on vahva. Tällainen työ on ilman muuta tärkeää ja auttaa ymmärtämään Husserlin kirjoituksia, mutta ei kuitenkaan korvaa fenomenologiaa. Juhlakirjassa fenomenologialla onneksi on vielä vahva paino.

Françoise Dastur aloittaa oman artikkelinsa ("René Char, Dichter der Nacht und des Blitzes") kysymällä voimmeko ylipäänsä sanoa mitään runoista. Charin runoja ei kiiruhdeta heti selittelemään vaan ensin etsitään mieltä koko selvitykselle. Tällainen harkitsevainen ote on kirjan parasta antia, vaikka joissakin artikkeleissa tuo ote tun- 
tuukin joskus unohtuvan ("fenomenologinen teoria"?). Toivokaamme että tälle harkitsevuudelle on tässä akateemisessa maailmassa aikaa jatkossakin.

\section{Juha Himanka}

